\title{
Occurrence of Ulva lactuca L. 1753 (Ulvaceae, Chlorophyta) at the Murman Coast of the Barents Sea
}

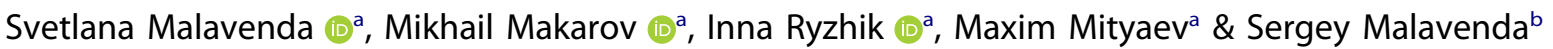 \\ aLaboratory of Algology, Murmansk Marine Biological Institute, Murmansk, Russia; bepartment of Biology, Murmansk State Technical \\ University, Murmansk, Russia
}

\section{ABSTRACT}

Findings of Ulva lactuca L. on the Murman Coast of the Barents Sea are described for the period 2009-2017. This species has not been found in this area for more than 50 years. The occurrence of $U$. lactuca on the Murman Coast appears to be related to the recent warming of waters in the region.

\section{KEYWORDS}

Sea lettuce; seaweed; climate change; global warming; Arctic; berealization

\section{Introduction}

The present study aims to give an overview on the distribution of Ulva lactuca Linnaeus 1753: 1163 (Chlorophyta, Ulvaceae) in the Barents Sea. In the World Ocean, this species is very widespread (Guiry \& Guiry 2018), found almost everywhere in shallow waters, including estuaries. The temperature and light tolerance of the species are well studied. Photosynthesis has been observed at temperatures ranging from $0^{\circ} \mathrm{C}$ to $28^{\circ} \mathrm{C}$ (Lüning 1984), with the highest growth rate occurring at $10-15^{\circ} \mathrm{C}$ (Fortes \& Lüning 1980). At water temperatures of $7^{\circ} \mathrm{C}$ and $10^{\circ} \mathrm{C}$, U. lactuca can adapt to low illumination levels (Vermaat \& Sand-Jensen 1987; Sand-Jensen 1988). However, it is still unclear how $U$. lactuca responds to the combination of low illumination and low temperature. At the northern margin of its geographical range, $U$. lactuca findings are random and rare: it has been found on the western, southern and the northern shores of Svalbard (Vinogradova 1995; Gullikssen et al. 1999), Novaya Zemlya (Štrik et al. 2000) and on the coasts of Norway (Brattegard et al. 2001) and Alaska (Hayden \& Waaland 2004; Lindeberg \& Lindstrom 2010). The harsh wintertime conditions of the polar region - low temperature and lack of light (limiting photosynthesis) - is likely the reason for the weak expansion of species in the Arctic seas.

On the Murman Coast, U. lactuca was found in Olenii Strait (22 September 1930), in Kola Bay (1 June 1932) and in Podpakhta Bay 30 years later (2 July1961) (Vinogradova 1974). Species lists compiled later do not mention U. lactuca (e.g., Šošina \&
Averintseva 1994; Šošina 2003; Zavalko \& Šošina 2008) and even question the presence of this species in the Barents Sea. Analysis of these data indicates the instability of the presence of $U$. lactuca on the Murmansk coast.

In recent decades, temperatures in the Barents Sea have risen following the increased inflow of Atlantic water masses during spring (Matishov et al. 2009; Matishov et al. 2014; MMBI 2017). It is possible that these water masses also brought spores, gametes or zygotes of $U$. lactuca, which developed in Zelenetskaya Bay under the more favourable conditions.

Part of the long-term monitoring of the state of coastal phytocenoses of the Murman Coast and the Russian archipelagos of the Barents Sea, this study aims to present the latest findings of $U$. lactuca on the Murman Coast and to consider their possible relationship with the positive temperature anomalies of the coastal water masses in the Barents Sea.

\section{Materials and methods}

A study of the species composition of the phytocenoses of the Murman Coast was carried out each year from 2009 to 2017, mainly in the summer (June-September). During this period 12 different sites from Pechenga Bay in the east $\left(69^{\circ} 36^{\prime} \mathrm{N} 31^{\circ}\right.$ $\left.21^{\prime} \mathrm{E}\right)$ to Ivanovskaja Bay in the west $\left(68^{\circ} 17^{\prime} \mathrm{N}\right.$ $38^{\circ} 44^{\prime} \mathrm{E}$ ) of the Murman Coast were investigated, spanning a distance of about $300 \mathrm{~km}$ (Fig. 1). Algae were sampled with a standard geobotanic method, using a frame with an area of

CONTACT Svetlana Malavenda malavenda@yandex.ru E Murmansk Marine Biological Institute, Kola Scientific Center, Russian Academy of Sciences (MMBI KSC RAS), Vladimirskaya St. 17, Murmansk 183010 Russia 


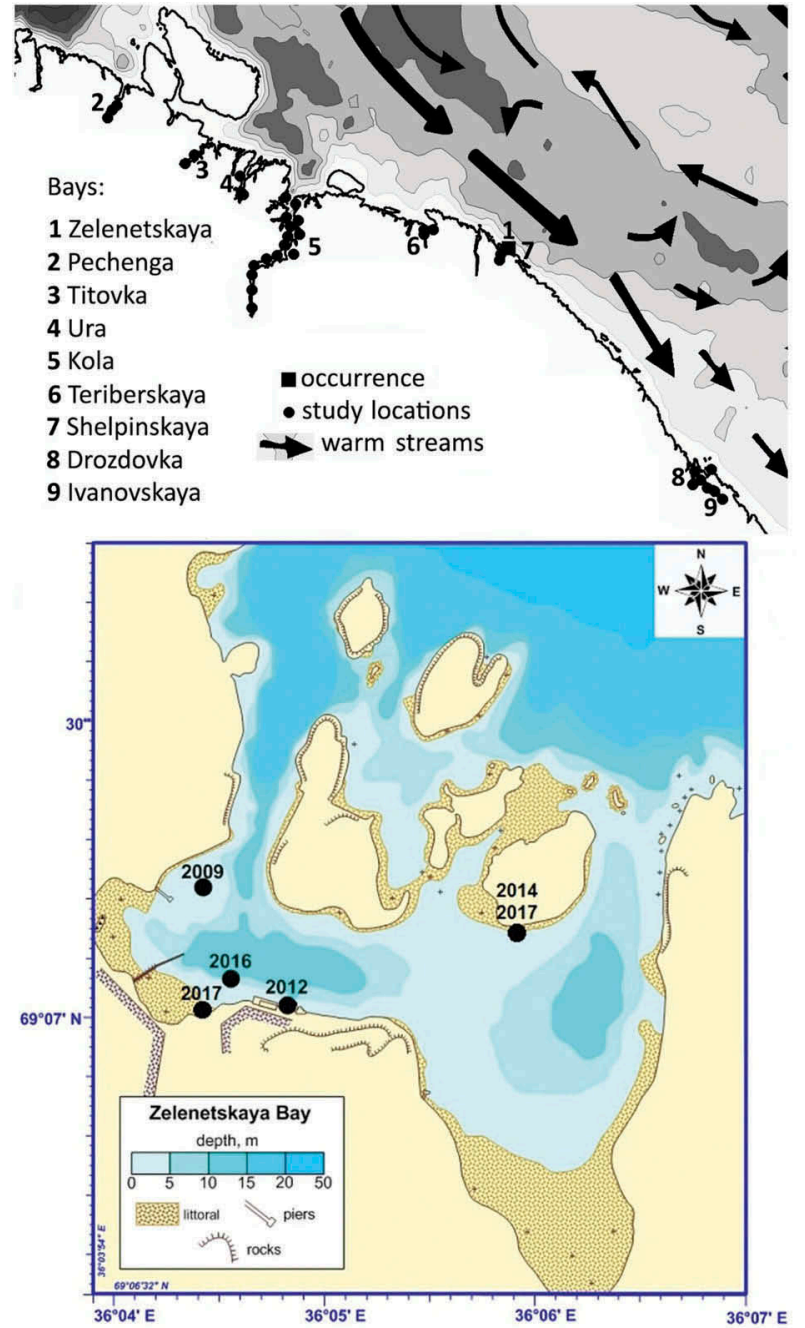

Figure 1. The study area on the Murman Coast. Inset: Zelenetskaya Bay, indicating where Ulva lactuca was found in 2009-2017.

$0.25 \times 0.25 \mathrm{~m}$, with three replicas, on the upper, middle and lower littoral. On the entire accessible part of the littoral of the bays, qualitative surveys of species composition were also carried out.

Ulva lactuca was identified using the description of Vinogradova (1974). We relied on morphological features because the genetic analysis of Ulva lactuca and another species of Ulva gathered in other areas (Malta et al. 1999; Hayden \& Waaland 2002; Hayden et al. 2004) has shown these to characterize the species. Ulva lactuca is characterized by a bright green solid thallus, attached to the substrate by a small rhizoid part (stems and sack-like base are absent). The thallus is bilayered, without a cavity. The cells are arranged chaotically, somewhat elongated in the transverse section, their size ranging from 12 to 23 $\mu \mathrm{m}$, in most cases $15-20 \mu \mathrm{m}$. The chloroplasts are lamellar, in mature thallus, granular. There are one to two (occasionally three) pyrenoids in the cells, but sometimes they are indistinctly visible.

Differentiation of $U$. lactuca and $U$. rigida was not carried out in this study due to the lack of clear species criteria. All the found thalli with the described set of characteristics were considered U. lactuca. Ulva rigida has not previously been noted in the Barents Sea, and we do not consider it reasonable to introduce this species into the flora on the basis of this single sample. Further study is needed in order to determine whether $U$. rigida is present in the region.

The material is stored at the Murmansk Biological Institute (Murmansk, Russia). One of the samples was given to the Herbarium of the Komarov Botanical Institute of the Russian Academy of Sciences (St. Petersburg, Russia).

\section{Results and discussion}

Murman's coastal biocenoses were first systematically studied in the period from 1912 through the 1930s. The Barents Sea underwent a warming in the early 1930s (Matishov et al. 2009; Matishov et al. 2014), when findings of U. lactuca (Vinogradova 1974) on the Murman Coast were first described. The second period of intensive algological research was from 1985 to the 1990s, when the list of species of Yarnyshnaya Bay, in the eastern part of the Murman Coast, was drawn up (Šošina \& Averintseva 1994). At that time, negative temperature anomalies were observed (Matishov et al. 2009; Matishov et al. 2014) and the species was not on the list.

The most recent period in the study of the algal communities of the Murman Coast began in 2009. Thalli of U. lactuca (Fig. 2) were found exclusively in Zelenetskaya Bay $(69.10 \mathrm{~N}, 36.05 \mathrm{E})$ in 2009, 2012, 2014, 2016 and 2017 (Table 1). Although Zelenetskaya Bay had been carefully surveyed in earlier years, 2009 was the first year in which signs of U. lactuca were observed there. In 2009, 2012, 2014 and 2016, single specimens of this species were encountered in Zelenetskaya Bay, with the first finding being made in the sublittoral community (Fig. 1). In 2017, U. lactuca was noted many times on the boulders of the lower littoral, protected from the surf (Supplementary Fig. S1), and also at the experimental farm of Saccharina latissima (Linnaeus) Lane, Mayes, Druehl \& Saunders 2006 and Fucus vesiculosus L. 1753. Attachment of $U$. lactuca spores on the ropes of the experimental plot could only happen by way of self-planting from the water column since the thalli of S. latissima and F. vesiculosus, woven into lines, were sampled directly from the bay. The other seaweeds came from the bay, so U. lactica must have landed on the ropes by itself, via the water.

In 2016 and 2017, the size of the cells of U. lactuca specimens grown on the farm ropes had smaller cells

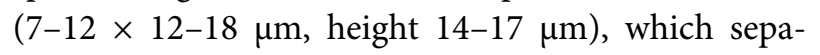
rates these algae from those grown at the bottom 


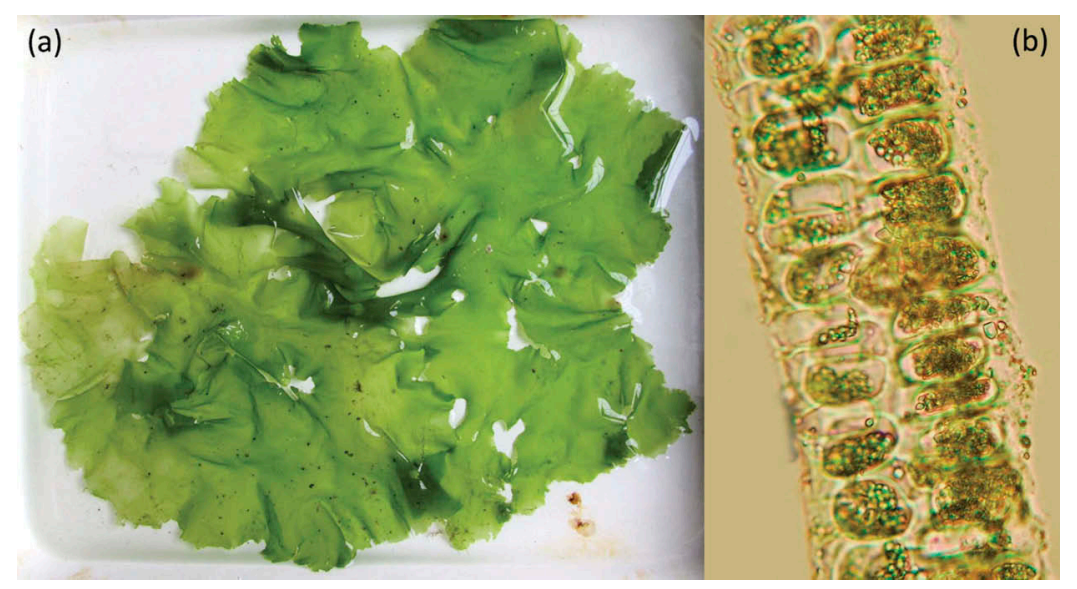

Figure 2. (a) The appearance of the Ulva lactuca thallus found in Zelenetskaya Bay, July 2017; (b) the transverse section of the thallus, viewed through a microscope.

Table 1. Brief description of the sites in Zelenetskaya Bay where Ulva lactuca was found and the morphological parameters of the specimens. Sporangia were present only in the specimen found on 3 August 2016 (marked in boldface).

\begin{tabular}{|c|c|c|c|c|c|}
\hline $\begin{array}{l}\text { Date } \\
\text { (dd/mm/yy) }\end{array}$ & Site description & $\mathrm{T}\left({ }^{\circ} \mathrm{C}\right)$ & $\begin{array}{l}\text { Number } \\
\text { of } \\
\text { specimens }\end{array}$ & Thallus size $(\mathrm{cm})$ & Cell size $(\mu \mathrm{m})$ \\
\hline $26 / 08 / 09$ & Sublittoral, $2 \mathrm{~m}$, bottom community of Saccharina latissima & 7.2 & 2 & $15 \times 207 \times 10$ & $15-20$ \\
\hline 03/07/12 & Littoral, bottom community of Fucus distichus $+F$. vesiculosus & 7.7 & 2 & $3 \times 44 \times 5$ & $15-20$ \\
\hline $10 / 08 / 14$ & Littoral, bottom community of Fucus distichus $+F$. vesiculosus & 6.7 & 1 & $17 \times 15$ & $15-18$ \\
\hline 03/08/16 & Seaweed farm (S. latissima), on the rope, near the surface & 9.2 & 1 & $18 \times 25$ & 10-15 \\
\hline $13 / 08 / 17$ & $\begin{array}{l}\text { Lower littoral, an area protected from the violent churning } \\
\text { along coastline, between Monostroma grevillei at the } \\
\text { bottom substrate }\end{array}$ & 7.5 & 1 & $1 \times 2$ & $15-20$ \\
\hline $14 / 08 / 17$ & Seaweed farm (S. latissima), on the rope, near the surface & 8.7 & 1 & $6 \times 7$ & $12-15$ \\
\hline $21 / 08 / 17$ & $\begin{array}{l}\text { Lower littoral of Zhiloi Island, at the margin of the rockweeds } \\
\text { and kelp }\end{array}$ & 9.3 & $>20$ & $0.2 \times 1-2 \times 5$ & $15-20$ \\
\hline 05/09/17 & $\begin{array}{l}\text { Lower littoral of Zhiloi Island, at the margin of the rockweeds } \\
\text { and kelp }\end{array}$ & & 2 & $2 \times 3$ and $3 \times 4$ & $15-20$ \\
\hline
\end{tabular}

substrate, although the plants themselves were outwardly typical (Supplementary Fig. S2).

Finding U. lactuca in Zelenetskaya Bay confirms the presence of the species on the Murman Coast, and adds to observations of the occurence of the species on other Barents Sea coasts. It also raises a number of questions, since, of all the areas of the Murman Coast that were surveyed in recent years, $U$. lactuca was found only in Zelenetskaya Bay.

Zelenetskaya Bay (in some publications, Dal'nezelenetskaya) is protected from the direct action of the surf by a group of islands to the north. The bay shape is square, about $2 \mathrm{~km}$ across. Depths do not exceed $18 \mathrm{~m}$. The substrate in the protected part of the bay is silty-sandy, with a small amount of medium-sized and small stones, and in the straits and along the edge of the shore there are boulders. There are two inlets in the bay: the south-western inlet (Oscar Inlet) and a much larger south-eastern inlet. The average annual temperature of the surface waters is $3.8 \pm 0.1^{\circ} \mathrm{C}$ (Mitjaev 2014). There are two independent currents in the bay: the waters enter and exit through the western and eastern straits, moving in the inlets counter-clockwise (Mitjaev 2014). The hydrological regime of Zelenetskaya Bay differs even from the adjacent Yarnyshnaya Bay on account of different physical and geographical conditions (Gromov et al. 2010; Mitjaev 2014).

In 1983-84, the water temperature in the $0-15 \mathrm{~m}$ layer of Zelenetskaya Bay dropped to $-1.5^{\circ} \mathrm{C}$ in January, and a steady rise in the water temperature was observed only from the end of April. In JuneJuly, the temperature of the water was less than $7^{\circ} \mathrm{C}$, and only at the end of August and September was there an increase to $9^{\circ} \mathrm{C}$ (Bardan \& Širokolobov 1988). Since 1998, coastal waters have warmed (Matishov et al. 2009; Matishov et al. 2014). In 2002-2012, the average annual temperature of the surface water layer in Zelenetskaya Bay was $3.8^{\circ} \mathrm{C}$, and the average monthly temperature in JulySeptember exceeded $7^{\circ} \mathrm{C}$. In winter, it did not drop below $0.7^{\circ} \mathrm{C}$ (Il'in et al. 2016). Oceanographic studies have revealed continuing positive thermohaline anomalies in the spring and summer in 2016 and 2017, indicating the increased inflow of waters of Atlantic origin into the Barents Sea (Moiseev \& Žičkin 2017).

Observations of a sharp increase in U. lactuca occurrences in Zelenetskaya Bay in 2017 suggest a relationship with the warming of the bay. It is likely that warmer conditions in the spring and in the first half of summer contribute to the survival and growth 
of $U$. lactuca. The ability of this species to reproduce vegetatively in extreme environmental conditions, as well as the viability of zygotes for several months, allows them to spread over long distances (Vinogradova 1974). It is probable that U. lactuca zygotes are transported to the study area by the currents coming from the coast of the Scandinavian Peninsula, and in warmer periods they can germinate and develop. Adult plants demonstrate a high tolerance to low temperature (Fortes \& Lüning 1980; Lüning 1984; Vermaat \& Sand-Jensen 1987; SandJensen 1988); however, the temperature sensitivity of spores, gametes and zygotes of this species has not been investigated. Unicellular stages may be more sensitive to stress and are probably unlikely to survive high-latitude wintertime conditions of low temperatures and little light.

A similar pattern in the distribution of the species at the northern margin of the geographical range was noted in Spitsbergen: studies conducted in 1988 in the southern part of the archipelago Hornsund fjord, Sørkappland - did not find this species; but in 2007-08 it was noted (Weslawski et al. 2010). The authors attribute the appearance of $U$. lactuca with the increase in the mean water temperature: the average temperature in Hornsund in summer also exceeds $7^{\circ} \mathrm{C}$. In the Novaya Zemlya Archipelago, U. lactuca was identified in the collections made in 1994-95 in the Yugorsky Shar Strait, in Chernaya Bay and at Mestnyi Island, and in Ivanova Bay in 1995 (Štrik et al. 2000), although the species was not found earlier in this region (Gemp \& Byzova 1976). These findings may be associated with the warming period of the southeastern Barents Sea in 1990-95 (Griŝenko 2010). The findings of $U$. lactuca in Olenii Strait and in Kola Bay in the 1930s and in Podpakhta Bay in the 1960s (Vinogradova 1974) may also be related to climatic conditions of those times (Matishov et al. 2009; Matishov et al. 2014; Mitjaev 2014).

Thus, the analysis of the periodicity of the findings of $U$. lactuca in various areas of the Barents Sea suggests a connection of its recent poleward expansion with an increase of the water temperature.

\section{Acknowledgements}

The authors are grateful to T.A. Mikhailova for help in transferring material to the Komarov Botanical Institute Herbarium

\section{Disclosure statement}

No potential conflict of interest was reported by the authors.

\section{Funding}

This work was financially supported by project no. RFMEFI61616X0073 (MEMO-PRO) funded by the Ministry of Education and Science of the Russian Federation.

\section{ORCID}

Svetlana Malavenda (D) http://orcid.org/0000-0002-83143255

Mikhail Makarov (D) http://orcid.org/0000-0001-9277-6292

Inna Ryzhik (D) http://orcid.org/0000-0003-3874-2379

\section{References}

Bardan S.I. \& Širokolobov V.N. 1988. Gidrologogidrohimičeskie issledovanija. (Hydrological-hydrochemical research.) In V.G. Averincev et al. (eds.): Kontrol' e'kologicheskoj situacii $v$ rajone opy'tno-promy 'shlennoj plantacii $v$ gube Dal'nezeleneczkaya (operativny'j informacionny'j material). (Control of the environmental situation in the area of the experimental seaweed farm in Dalnezelenetskaya Bay. Operational and information material.) Pp. 7-23. Apatity: Kola Scientific Center of the Russian Academy of Sciences.

Brattegard T. \& Holthe T. (eds.) 2001. Distribution of marine, benthic macro-organisms in Norway. A tabulated catalogue. Research Report 2001-3. (Updated version of report DN 1997-1.) Trondheim: Directorate for Nature Management.

Fortes M.D. \& Lüning K. 1980. Growth rates on North Sea macroalgae in relation to temperature, irradiance and photoperiod. Helgoländer Meeresuntersuchungen 34, 15-29.

Gemp K.P. \& Byzova L.N. 1976. Vodorosli proliva Karskie Vorota (južnoe poberež'e Novoj Zemli). (The algae of the Kara Strait, south coast of Novaya Zemlya.) Materialy Rybohozaistvennih Issledovaniy Severnogo Bassejna (Fisheries Research in the Northern Basin) 12, 102-110.

Griŝenko V.I. 2010. Izmenenija klimata na akvatorii ûgovostočnoj časti barenceva morja. (Climate change in the waters of the south-east Barents Sea.) In G.G. Matišov \& G.A. Tarasov (eds.): Priroda šel'fa i arhipelagov evropejskoj Arktiki. Kompleksnye issledovanija prirody Špicbergen. (Proceedings of the International Scientific Conference Nature of the Shelf and Archipelagos of the European Arctic. Complex Investigations of the Svalbard Archipelago Nature. Murmansk, Russia, 27-30 October 2010.) Pp. 68-72. Moscow: GEOS.

Gromov M.S., Moiseev D.V. \& Sirokolobov D.V. 2010 The hydrometeorological conditions in the Yarnyshnaya and Zelenetskaya bays of the Barents Sea in the summer of 2009. In G.G. Matišov \& G.A. Tarasov (eds.): Priroda šel'fa i arhipelagov evropejskoj Arktiki. Kompleksnye issledovanija prirody Špicbergen. (Proceedings of the International Scientific Conference Nature of the Shelf and Archipelagos of the European Arctic. Complex Investigations of the Svalbard Archipelago Nature. Murmansk, Russia, 27-30 October 2010.) Pp. 72-79. Moscow: GEOS.

Guiry M.D. \& Guiry G.M. 2018. AlgaeBase. Database maintained by National University of Ireland, Galway. Accessed on the internet at http://www.algaebase.org 1 March 2018. 
Gulikssen B., Palerud R., Brattegard T. \& Sneli J. (eds.) 1999. Distribution of marine benthic macro-organisms at Svalbard (including Bear Island) and Jan Mayen. Research Report DN 1999-4. Trondheim: Directorate for Nature Management.

Hayden H.S. \& Waaland J.R. 2002. Phylogenetic systematics of the Ulvaceae (Ulvales, Ulvophyceae) using chloroplast and nuclear DNA sequences. Journal of Phycology $38,1200-1212$.

Hayden H.S. \& Waaland J.R. 2004. A molecular systematic study of Ulva (Ulvaceae, Ulvales) from the northeast Pacific. Phycologia 43, 364-382.

Il'in G.V., Moiseev D.V., Širokolobov D.V., Derjabin A.A. \& Pavlova L.G. 2016. Gidrologičeskij režim guby Zeleneckaja, Vostočnyj Murman. (Long-term dynamics of the hydrological conditions of Zelenetskaya Bay, east Murman.) Vestnik MSTU 19, 268-277.

Lindeberg M.R. \& Lindstrom S.C. 2010. Field guide to the seaweeds of Alaska. Fairbanks: Alaska Sea Grant College Program.

Lüning K. 1984. Temperature tolerance and biogeography of seaweeds: the marine algal flora of Helgoland (North Sea) as an example. Helgoländer Meeresuntersuchungen 38, 305-317.

Malta E.J., Draisma S.G.A. \& Kamermans P. 1999. Freefloating Ulva in the southwest Netherlands: species or morphotypes? A morphological, molecular and ecological comparison. European Journal of Phycology 34, 443-454.

Matishov G.G., Berdnikov S.V., Zhichkin A.P., Dzhenyuk S.L., Smolyar I.V., Kulygin V.V., Yaitskaya N.A., Povazhniy V.V., Sheverdyaev I.V., Kumpan S.V., Tretyakova I.A., Tsygankova A.E., D'yakov N.N., Fomin V.V., Klochkov D.N., Shatohin B.M., Plotnikov V.V., Vakulskaya N.M., Luchin V.A. \& Kruts A.A. 2014. Atlas of climatic changes in nine large marine ecosystems of the Northern Hemisphere (1827-2013). International Ocean Atlas and Information Series 14. NOAA Atlas NESDIS 78. Silver Spring, MD: National Environmental Satellit. Data, and Information Service, National Oceanic and Atmospheric Administration, US Dept. of Commerce. Doi: 10.7289/V5Q52MK5.

Matishov G.G., Matishov D.G. \& Moiseev D.V. 2009. Inflow of Atlantic-origin waters to the Barents Sea along glacial troughs. Oceanologia 51, 321-340.

Mitjaev M.V. 2014. Murmanskoe pobereže (geologogeomorfologičeskie i klimatičeskie osobennosti, sovremennye geologičeskie processy). (Murman Coast. Geological, geomorphological and climatic features, current geological processes.) Apatity: Kola Scientific Center, Russian Academy of Sciences.

MMBI 2017. Biologičeskie resursy arktičeskih morej Rossii: sovremennoe sostojanie, vlijanie prirodnyh izmenenij $i$ antropogennogo vozdejstvija, naučnaja osnova i perspektivy ispol'zovanija. (Biological resources of Russia's Arctic seas: current state, the influence of natural changes and anthropogenic effects, the scientific basis and perspectives of use for the period 2014-17.) Murmansk: Murmansk Marine Biological Institute, Kola Scientific Center, Russian Academy of Sciences.

Moiseev D.V. \& Žičkin A.P. 2017. Termohalinnye uslovija $\mathrm{v}$ prikromočnoj zone na severe Barenceva morja v aprele 2016 goda. (Thermohaline conditions of the ice edge area in the northern Barents Sea in April 2016.) Trudy Kol'skogo Naučnogo Centra RAN 8, 10-25.

Sand-Jensen K. 1988. Photosynthetic responses of Ulva lactuca at very low light. Marine Ecology Progress Series 50, 195-201.

Šošina E.V. 2003. Makrofity. (Macrophytes.) In L.L. Kuznecov \& E.V. Šošina (eds.): Fitocenozy Barenceva morâ (fiziologičeskie $i$ strukturnye harakteristiki). (Phytocenoses of the Barents Sea. Physiological and structural characteristics.) Pp. 177-304. Apatity: Kola Scientific Center, Russian Academy of Sciences.

Šošina E.V. \& Averinceva S.G. 1994. Raspredelenie associacij vodoroslej, vidovoj sostav i biomassa $v$ gube jarnyšnoj Barenceva morja. (Distribution of the algal community, their species diversity and biomass in Yarnyshnaia Bay of the Barents Sea.) In G.G. Matišov (ed.): Gidrobiologičeskie issledovanija $v$ gubah $i$ zalivah severnyh morej Rossii. (Hydrobiological research in the bays and coves of Russia's northern seas.) Pp. 38-61. Apatity: Kola Scientific Center, Russian Academy of Sciences.

Štrik V.A., Vozžinskaja B.V. \& Vehov N.V. 2000. Morskie vodorosli poberežja Novoj Zemli i proliva jugorskij šar. (Marine algae of the coast of Novaya Zemlya and the Jugorskiy Shar Strait.) In A.A. Nejman \& M.I. Tarverdijeva (eds.): Morskie gidrobiologičeskie issledovanija. (Marine hydrobiological studies.) Pp. 88-98. Moscow: Russian Research Institute of Fisheries and Oceanography.

Vermaat J.E. \& Sand-Jensen K. 1987. Survival, metabolism and growth of Ulva lactuca under winter conditions: a laboratory study of bottlenecks in the life cycle. Marine Biology 95, 55-61.

Vinogradova K.L. 1974. Ul'vovye vodorosli (Chlorophyta) morej SSSR. (Ulvaceous algae [Chlorophyta] of the seas of the USSR.) Leningrad (St. Petersburg): Nauka.

Vinogradova K.L. 1995. The checklist of the marine algae from Spitsbergen. Botaničeskij Žurnal 80, 50-61.

Weslawski J.M., Wiktor J. Jr \& Kotwicki L. 2010. Increase in biodiversity in the Arctic rocky littoral, Sorkappland, Svalbard, after 20 years of climate warming. Marine Biodiversity 40, 123-130.

Zavalko S.E. \& Šošina E.V. 2008. Mnogourovnevaja morfofiziologičeskaja ocenka sostojanija fukusovyh vodoroslej v uslovijah antropogennogo zagrjaznenija (Kol'skij zaliv, Barencevo more). (Multilevel morphophysiological investigation of brown algae, Kola Bay, Barents Sea.) Vestnik MGTU 11, 423-431. 